\title{
PENGARUH EKSTRAK DAUN BINAHONG (Anredera cordifolia (Ten.) Steenis) TERHADAP PERTUMBUHAN BAKTERI Streptococcus pyogenes SECARA IN VITRO
}

\author{
Yuliana Prasetyaningsih ${ }^{{ }^{*}}$,Eni Kurniati ${ }^{2}$, Dina Setiarini ${ }^{3}$ \\ ${ }^{1,3}$ Prodi D3 Analis Kesehatan, STIKES Guna Bangsa Yogyakarta, Jl. Ring Road Utara \\ Condongcatur Depok Sleman Yogyakarta telp. 0274-4477701, 4477703, 4477704 \\ fax.0274-4477702 \\ 2Jurusan Analis Kesehatan, POLTEKKES Kemenkes Yogyakarta \\ Email: yulianaprasetya@gmail.com
}

\begin{abstract}
Background: Infectious diseases are diseases caused by pathogenic bacteria such as Streptococcus pyogenes bacteria. This bacterium is a gram-positive, cocci-shaped chain that infect the respiratory tract. As a result of irrational use of antibiotics is causing bacterial resistance. Utilization of plants used in traditional medicine as an alternative by some people. Binahong (Anredera cordifolia (Ten.) Steenis) is a plant that can be used as a traditional medicine can be found easily in Indonesia. Binahong is one of the medicinal plants are thought to have antibacterial effects.
\end{abstract}

Objective: To investigate the effect of leaf extracts binahong (Anredera cordifolia (Ten) Steenis) against Streptococcus pyogenes bacterial growth in vitro.

Research Methods: The study was conducted in July 2014 in the Laboratory of Bacteriology of Ministry of Health polytechnic Yogyakarta. Types experimental research is real by using desain one-short case study. Binahong leaves were tested came from Yogyakarta Sleman. Analysis of the data obtained and performed descriptive statistics and presented in tables or graphs. The statistical test used is one way analysis of variance (One Way Anova).

Result: The mean diameter of inhibition zone binahong leaf extract on the growth of the bacterium Streptococcus pyogenes at the smallest concentration that is $20 \%$ of $12.3 \mathrm{~mm}$ and largest concentration of $100 \%$ at $23.6 \mathrm{~mm}$.

Conclusion: there is influence binahong leaf extract against Streptococcus pyogenes growth in vitro.

Keywords: Antibacterial, Inhibitory zone, Binahong, Streptococcus pyogenes.

\section{PENDAHULUAN}

Penyakit infeksi masih menempati urutan teratas penyebab penyakit dan kematian di negara berkembang, termasuk Indonesia. Tingginya angka kejadian infeksi di masyarakat akan menyebabkan penurunan produktifitas nasional secara umum, sedangkan di lain pihak menyebabkan peningkatan pengeluaran untuk upaya pengobatan (Wahyono, 2007).

Penanggulangan penyakit infeksi biasanya menggunakan antibiotik 
(Refdanita dkk., 2004). Antibiotik mempunyai peran penting untuk mengatasi infeksi karena bakteri. Antibiotik diharapkan mampu mengeliminasi bakteri penyebab infeksi. Tetapi jika penyalahgunaan antibiotik dan kesalahan pemilihan antibiotik dapat menyebabkan resistensi yang dapat mempengaruhi laju perjalanan infeksi (Dzen, 2003).

Menurut hasil survei Kesehatan Rumah Tangga 2004, prevalensi karies gigi di Indonesia adalah 90,05 \%. Patogenitas Streptococcus mutans sebagai penyebab utama karies gigi dipercaya dapat mengganggu biologi rongga mulut. WHO pada tahun 2003 menyatakan bahwa karies gigi merupakan proses infeksi yang memiliki keterkaitan dengan kesehatan dan status gizi serta dapat bertindak sebagai fokal infeksi yang dapat menimbulkan penyakit organ tubuh lainnya.

Penggunaan obat yang tidak rasional dapat menimbulkan resistensi sejumlah bakteri, sehingga perlu dilakukan penelitian untuk mencari obat alternatif yang murah dan mudah didapat dengan memanfaatkan tanaman (Uchida, 2003). Penggunaan obat yang tidak rasional adalah obat yang tidak sesuai dengan kebutuhan klinis pasien dalam jumlah dan untuk dosis yang sesuai. Dampak buruk penggunaan obat yang tidak rasional dan penggunaan antibiotik yang berlebihan yaitu menyebabkan ekologi pada bakteri. Pemberian antibiotik dikatakan tepat bila efek terapi mencapai maksimal sementara efek toksik yang berhubungan dengan obat menjadi minimal, serta resisten seminimal mungkin (Sadikin, 2011).

Resistensi terhadap antibiotik adalah perubahan kemampuan bakteri hingga menjadi kebal terhadap antibiotik. Bakteri ini resisten terhadap penisilin, oksasilin, dan antibakteri lactam lainnya (Fontana, dkk., 1990). Bakteri Streptococcus pyogenes (Streptococcus grup A) merupakan salah satu penyebab infeksi saluran nafas. Kerongkongan merupakan tempat pertama yang diserang hingga menyebabkan nyeri menelan. Bakteri ini sering terkumpul pada tonsil atau juga dapat menyerang faring (Gupte, 2004). Streptococcus pyogenes merupakan bakteri pathogen yang banyak menginfeksi manusia.

Pemanfaatan tumbuh-tumbuhan sebagai obat tradisional berkembang pesat dan banyak dijadikan obat alternatif oleh sebagian masyarakat. Obat tradisional merupakan bahan atau ramuan berupa bahan tumbuhan, bahan hewan, bahan mineral, sediaan sarian atau bahan campuran dari bahan tersebut yang secara turun temurun telah digunakan untuk pengobatan berdasarkan pengalaman yang sudah dilakukan (Tjai dan Rahardja, 2007).

Daun binahong (Anredera cordifolia (Ten.) Steenis) dalam kultur in vitro mengandung beberapa senyawa metabolit sekunder antara lain flavonoid, alkaloid, terpenoid, dan saponin. Aktivitas farmakologi flavonoid adalah sebagai anti-inflamasi, dan antioksidan, alkaloid sebagai hipoglikemik. Terpenoid dapat membantu tubuh dalam proses sintesis organik dan pemulihan sel-sel tubuh, sedangkan saponin berperan untuk menurunkan kolesterol dan anti karsinogenik (Manoi, 2009). Gambar 1 menunjukkan gambar daun binahong.

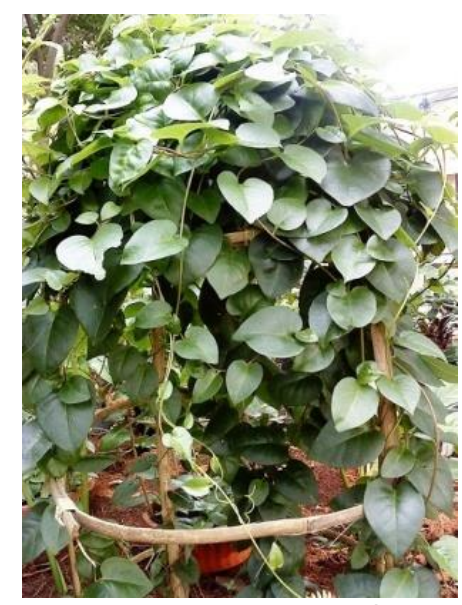

Gambar 1.Daun binahong (Anredera cordifolia (Ten.)Steenis) Sumber : Ervizal, 2012 


\section{METODE PENELITIAN}

Penanaman bakteri pada media Blood Agar Plate (BAP) Kapas lidi steril ke dalam suspense bakteri kemudian ditekan-tekan pada dinding tabung sehingga tidak terlalu basah, kemudian dioleskan pada permukaan media BAP hingga rata, kemudian pada setiap petri dibuat 5 sumuran menggunakan perforator yang terlebih dahulu dipanaskan, masing-masing sumuran berdiameter 5 $\mathrm{mm}$ dan ketebalan media $4 \mathrm{~mm}$. Mengisi ekstrak daun binahong (Anredera cordifolia (Ten.) Steenis) Pada setiap sumuran diberi $50 \mu$ l ekstrak daun binahong sehingga tiap-tiap lubang berisi larutan percobaan yang berlainan konsentrasinya. Diinkubasi pada suhu $37^{\circ} \mathrm{C}$ selama 24 jam. Pembacaan hasil dilakukan dengan beralaskan kertas berwarna gelap atau dengan latar belakang sedikit gelap, mengukur diameter zona irradikal dan zona radikal yaitu daerah jernih sekitar sumuran (tidak ada pertumbuhan bakteri) diukur dari ujung ke ujung yang lain melaui tengah sumuran (Soemarmo, 2000).
Metode yang digunakan dalam penelitian yaitu metode difusi dengan sumuran agar, dalam penelitian ini ekstrak daun binahong (Anredera cordifolia (Ten.) Steenis) mampu menghambat bakteri Streptococcus pyogenes karena terdapat zona hambat di sekitar sumuran. Hasil pengukuran diameter zona hambat disekitar sumuran agar pada ekstrak daun binahong dengan konsentrasi (20\%, $40 \%, 60 \%, 80 \%, 100 \%)$ terhadap pertumbuhan bakteri Streptococcus pyogenes, polyethylene glycol (PEG) $0,5 \%$ sebagai kontrol negatif dan kontrol positif menggunakan antibotik tetrasiklin $30 \mu \mathrm{g}$.

\section{HASIL}

Data hasil diameter zona hambat ekstrak daun binahong (Anredera cordifolia (Ten.) Steenis) terhadap pertumbuhan bakteri Streptococcus pyogenes yang dilakukan sebanyak 3 kali dalam satuan millimeter $(\mathrm{mm})$ dapat dilihat pada tabel 1.

Tabel 1. Hasil pengukuran diameter zona hambat pertumbuhan bakteri Streptococcus pyogenes

\begin{tabular}{|c|c|c|c|c|c|c|c|}
\hline Pengulangan & \multicolumn{5}{|c|}{$\begin{array}{c}\text { Diameter zona hambat pertumbuhan } \\
\text { bakteri Streptococcus pyogenes }\end{array}$} & $\begin{array}{c}\text { Kontrol } \\
\text { positif }(\mathrm{mm})\end{array}$ & $\begin{array}{c}\text { Kontrol } \\
\text { negatif }(\mathrm{mm}) \\
\end{array}$ \\
\hline Konsentrasi & $100 \%$ & $80 \%$ & $60 \%$ & $40 \%$ & $20 \%$ & \multirow[t]{5}{*}{ 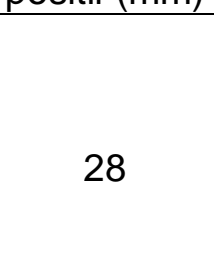 } & \multirow[t]{5}{*}{ 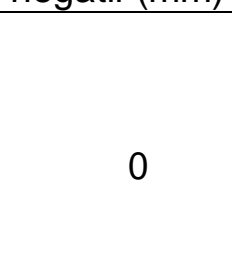 } \\
\hline Plate 1 & 24 & 23 & 20 & 17 & 13 & & \\
\hline Plate 2 & 24 & 22 & 20 & 18 & 12 & & \\
\hline Plate 3 & 23 & 22 & 21 & 17 & 12 & & \\
\hline Jumlah & 71 & 67 & 61 & 52 & 37 & & \\
\hline Rata-rata & 23,6 & 22,3 & 20,3 & 17,3 & 12,3 & 28 & 0 \\
\hline
\end{tabular}

Berdasarkan Tabel 1 hasil rata rata diameter zona hambat terbesar ekstrak daun binahong (Anredera cordifolia (Ten.) Steenis) terhadap pertumbuhan bakteri Streptococcus pyogenes terdapat pada konsentrasi $100 \%$ yaitu sebesar $23,6 \mathrm{~mm}$ sedangkan rata-rata terkecil diameter zona hambat terdapat pada konsentrasi $20 \%$ yaitu sebesar $12,3 \mathrm{~mm}$. pada konsentrasi $40 \%$ rata-rata zona hambat ekstrak daun binahong (Anredera cordifolia (Ten.) Steenis) sebesar 17,3 $\mathrm{mm}$, konsentrasi $60 \%$ sebesar 20,3 $\mathrm{mm}$, dan pada konsentrasi $80 \%$ sebesar 22,3 mm. Hasil Tabel 1 menunjukkan bahwa semakin besar konsentrasi ekstrak daun binahong (Anredera cordifolia (Ten.) Steenis) maka semakin besar pula diameter zona hambat yang terbentuk terhadap pertumbuhan bakteri Streptococcus 
pyogenes.

Hasil uji statistik deskriptif melalui program SPSS 17 for windows dari hasil data pada tabel 2 menggambarkan terdapat 15 data pengukuran zona hambat ekstrak daun binahong

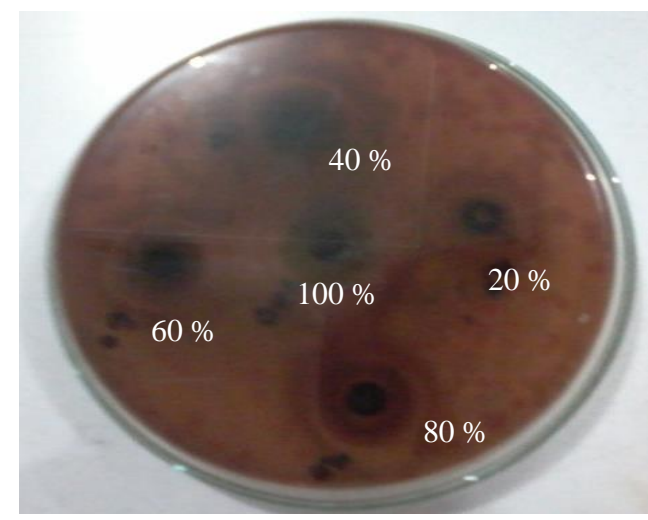

terhadap bakteri Streptococcus pyogenes dengan diameter minimum $12.0 \mathrm{~mm}$, diameter maksimum 24.0 $\mathrm{mm}$, nilai rata-rata $19.20 \mathrm{~mm}$ dan standar deviasi 4.21 .

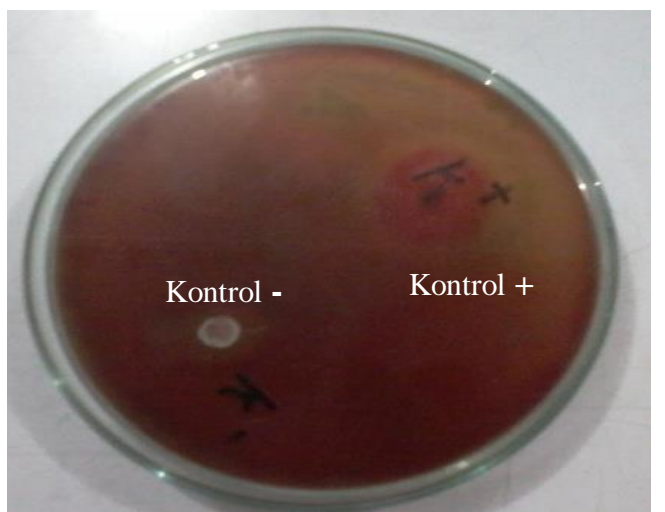

Gambar 2. Zona hambat yang terbentuk pada media BAP

Tabel 2. Hasil uji statistik deskriptif

\begin{tabular}{|c|c|c|c|c|c|c|}
\hline \multirow[b]{2}{*}{ Konsentrasi } & \multirow[b]{2}{*}{ Jumlah } & \multirow{2}{*}{$\begin{array}{l}\text { Rata- } \\
\text { rata }\end{array}$} & \multicolumn{2}{|c|}{$\begin{array}{c}\text { Tingkat } \\
\text { Kepercayaan } 95 \%\end{array}$} & \multirow[b]{2}{*}{ Minimum } & \multirow[b]{2}{*}{ Maksimum } \\
\hline & & & $\begin{array}{l}\text { Batas } \\
\text { Atas }\end{array}$ & $\begin{array}{l}\text { Batas } \\
\text { Bawah }\end{array}$ & & \\
\hline $20 \%$ & 3 & 12,33 & 10,89 & 13,76 & 12,00 & 13,00 \\
\hline $40 \%$ & 3 & 17,33 & 15,89 & 18,76 & 17,00 & 18,00 \\
\hline $60 \%$ & 3 & 20,33 & 18,89 & 21,76 & 20,00 & 21,00 \\
\hline $80 \%$ & 3 & 22,33 & 20,89 & 23,76 & 22,00 & 23,00 \\
\hline $100 \%$ & 3 & 23,66 & 22,23 & 25,10 & 23,00 & 24,00 \\
\hline Total & 15 & 19,20 & 16,86 & 21,53 & 12,00 & 24,00 \\
\hline
\end{tabular}

Grafik peningkatan besar diameter zona hambat yang terbentuk dari ekstrak daun binahong (Anredera cordifolia (Ten) steenis) terhadap bakteri Streptococcus pyogenes pada konsentrasi terkecil sampai konsentrasi terbesar dapat dilihat pada Gambar 3.

Uji statistik yang digunakan untuk mengetahui adanya pengaruh ekstrak daun binahong (Anredera cordifolia (Ten.) Steenis) terhadap pertumbuhan bakteri Streptococcus pyogenes secara invitro yaitu uji analisis varian satu jalan (One Way Anova) dengan taraf signifikan sebesar $5 \%(0,05)$ menggunakan program SPSS 17,0 for windows. Untuk mengetahui homogen atau tidaknya data hasil dimeter zona hambat ekstrak daun binahong (Anredera cordifolia (Ten.) Steenis) terhadap pertumbuhan bakteri
Streptococcus pyogenes maka dilakukan uji homogenitas. Pada uji homogenitas varian diperoleh hasil $p$ value (sig) 0,000. Selanjutnya dilakukan uji One Way Anova dan hasilnya dapat dilihat pada tabel 3 .

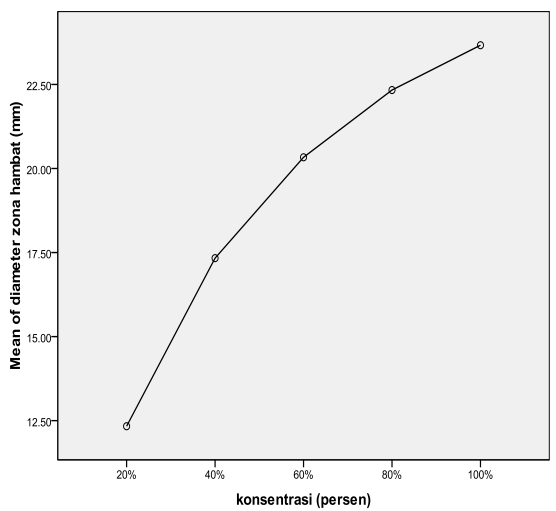

Gambar 3. Grafik Rata-Rata Diameter Zona Hambat Ekstrak Daun Binahong (Anredera Cordifolia (Ten.) Steenis). 
Tabel 3. Hasil uji One Way Anova

\begin{tabular}{|l|c|c|c|c|c|}
\hline & $\begin{array}{c}\text { Sum of } \\
\text { Squares }\end{array}$ & Df & $\begin{array}{c}\text { Mean } \\
\text { Square }\end{array}$ & $F$ & Sig. \\
\hline Between Groups & 245,06 & 4 & 61,2 & 183,80 & 0,00 \\
Within Groups & 3,33 & 10 & 6 & 0 & \\
Total & 248,40 & 14 & 0,33 & & \\
\hline
\end{tabular}

Hasil uji One Way Anova didapatkan nilai $F$ hitung sebesar 183,800 dan nilai $p$-value (sig) sebesar 0,000 atau $p<0,001$. Hipotesis pada uji One Way Anova adalah ada pengaruh ekstrak daun binahong (Anredera cordifolia (Ten.) Steenis) terhadap pertumbuhan bakteri Streptococcus pyogenes secara in vitro. Uji statistik One Way Anova menunjukan bahwa berbagai konsentrasi ekstrak daun binahong (Anredera cordifolia (Ten.) Steenis) dapat menghambat pertumbuhan bakteri Streptococcus pyogenes secara signifikan. Apabila pvalue (sig) dari data penelitian ledih besar dari nilai $p$-value (sig) sebesar 0,000 atau $p<0,001$, maka akan menggunakan hipotesis alterntif $\alpha=0,05$.

Hasil uji kemudian dilanjutkan pada uji Post Hoc (Tukey). Pada hasil uji ini dapat dilihat perbedaan yang "bermakna". Hasil yang bermakna yaitu dengan hasil $p$-value (sig) $<0,05$ atau lebih kecil dari a.hasil penelitian ini menunjukan $p$-value (sig) pada setiap konsentrasi lebih kecil dari $\alpha$, dapat disimpulkan bahwa terdapat pengaruh signifikan dan bermakana terhadap berbagai konsentrasi ekstrak daun binahong (Anredera cordifolia (Ten.) Steenis) terhadap pertumbuhan bakteri Streptococcus pyogenes secara in vitro.

\section{PEMBAHASAN}

Penelitian ini dilakukan untuk mengetahui pengaruh berbagai konsentrasi ekstrak daun binahong (Anredera cordifolia (Ten.) Steenis) terhadap pertumbuhan bakteri Streptococcus pyogenes secara in vitro. Metode penelitian ini menggunakan metode difusi sumuran agar. Metode sumuran menggunakan metode spread plate pada metode ini suspensi bakteri yang disamakan kekeruhannya dengan standar Mc farland $\left(10^{8} \mathrm{FCU} / \mathrm{ml}\right)$ lalu diteteskan pada media dan diratakan dengan kapas lidi steril metode ini lebih murah dan sederhana dibandingkan dengan metode difusi yang lain seperti metode pour plate yang membutuhkan banyak reagen dan menggunakan pengenceran bertingkat pada suspensi bakteri.

Pembacaan hasil metode difusi sumuran agar, menggunakan pengukuran zona hambat irradikal dengan mengukur adanya zona hambat disekitar sumuran. Pengukuran zona hambat terdapat zona radikal dan zona irradikal. Zona radikal merupakan zona disekitar sumuran dimana tidak ditemukan pertumbuhan bakteri sedangkan zona irradikal merupakan zona disekitar sumurun pertumbuhan bakteri hanya dihambat dan tidak dimatikan. Terbentuknya zona radikal karena bakteri sensitif terhadap suatu zat antibakteri dan zona irradikal disebabkan karena bakteri tidak sensitif terhadap suatu zat antibakteri (Brooks dkk.,2004).

Pada penanaman suspensi bakteri pada media BAP tidak teratur karena menggunakan kapas lidi steril apabila terlalu tebal akan menyebabkan diameter zona hambat kecil sedangkan apabila terlalu kecil akan menyebabkan zona hambat yang terbentuk terlalu besar tetapi pada penggunaan lidi steril akan memudahkan dalan maratakan suspensi pada media dan tidak merusak media BAP.

Pada hasil penelitian konsentrasi ekstrak daun binahong terkecil yaitu $20 \%$ sebesar $12,3 \mathrm{~mm}$ karena belum mencapai konsentrasi terkecil yang diinginkan maka perlu dilakukan penelitian lagi menggunakan konsentrasi dibawah $20 \%$. Konsentrasi 
tertinggi yaitu $100 \%$ sebesar $23,6 \mathrm{~mm}$ apabila dibandingkan dengan kontrol positif yang sebesar $28 \mathrm{~mm}$, maka lebih besar dibandingkan konsentrasi terbesar ekstrak daun binahong, akan tetapi ekstrak daun binahong dapat digunakan sebagai alternatif antibakteri dari bahan alami.

Pada penelitian yag dilakukan peralatan harus diseterilkan dengan oven agar tidak terjadi kontaminasi bakteri yang mengakibatkan kesalahan dalam penelitian, dan asptis dalam penanaman pada media karena media BAP mudah sangat subur. Diinkubasi pada suhu $37^{\circ} \mathrm{C}$ selama 24 jam sesuai dengan umur bakteri dan suhu pertumbuhan bakteri. Ada beberapa hal yang dapat menghambat dalam penelitian seperti penanaman bakteri yang kurang aseptis, kontaminasi, suhu inkubsi yang tidak tepat, keseterilan alat dan kualitas daun binahong.

\section{KESIMPULAN}

Berdasarkan hasil yang diperoleh dengan judul "pengaruh berbagai konsentrasi ekstrak daun binahong (Anredera cordifolia (Ten) Steenis) terhadap bakteri Streptococcus pyogenes secara in vitro" maka dapat ditarik kesimpulan sebagai berikut:

Terdapat pengaruh berbagai konsentrasi ekstrak daun binahong (Anredera cordifolia (Ten) steenis) terhadap pertumbuhan bakteri Streptococcus pyogenes secara in vitro.Rata-rata diameter zona hambat ekstrak daun binahong (Anredera cordifolia (Ten) steenis) terhadap pertumbuhan bakteri Streptococcus pyogenes pada konsentrasi $20 \%$ sebasar $12,3 \mathrm{~mm}$, padakonsentrasi $40 \%$ sebesar $17,3 \mathrm{~mm}$, pada konsentrasi $60 \%$ sebesar 20,3 mm, pada konsentrasi $80 \%$ sebesar $22,3 \mathrm{~mm}$ dan pada konsentrasi $100 \%$ sebesar 26,6 $\mathrm{mm}$.

\section{DAFTAR PUSTAKA}

Brooks, G., F., Butel, S., J., dan Morse S., A., 2004, Mikrobiologi Kedokteran, Edisi 1, EGC, Jakarta.

Cunningham, M.W.2000. Phatogenesis Of Group A Streptococcal Infection, Clin Microbiol Rev.470-511

Ervizal, dkk .2012 Khasiat 15 Tanaman Obat Unggulan Kampong Gunung Leutik. Institute Pertanian Bogor

Dzen, M. R. 2003. Bakteriologi Medic Edisi Pertama. Banyumedia. Malang.

Fontana., P., Canepari, M., Lieo, Dan G., Satta,1990, Mechanissms Of Resistance Of Enterococci To BetaLactam Antibiatics, European Journal Of Clinical Microbiology And Infection Diseases.

Gupte, S. 2004. Pedoman Perawatan Anak. Pustaka Popular Obor. Jakarta.

Manoi, F. dan Balittro. 2009. Binahong (Anredera Cordifolia) Sebagai Obat. Bogor : Pusat Penelitian dan Pengembangan Perkebunan.

Sadikin dan Zunilda Dj., 2011, Penggunaan Obat Rasional, Departemen Farmakologi Fakultas Kedokteran Universitas Indonesia, Jakarta, Jurnal Kesehatan Andalas.

Soemarmo, 2000. Isolasi dan Identifikasi Bakteri Klinik. Yogyakarta: Akademi Analis Kesehatan. Tjay, T.H.,dan Raharja,K.,2007. Obat-Obat Penting, Edisi ke 6. PT. Elex Komputindo, Jakarta.

Uchida, S. 2003. Production digital map of the hazardous condition of soil erosion for the sloping lans west java. Indonesia system (GIS) JIRCAS Indonesia.

Wahyono, H. 2007. Peran mikrobiologi pada penanganan penyakit infeksi. Makalah Pidato Pengukuhan Guru Besar Dalam IImu Mikrobiologi Fakultas Kedokteran Universitas Diponegoro. 